\title{
フッ素ドープ酸化亜鉛透明導電膜の低温合成
}

\author{
鯉沼秀臣・永田俊郎* ·佐々木 基** ・ 川崎雅司・高井 治*** \\ 水崎純一郎**** . 笛木 和 雄*** \\ 東京工業大学工業材料研究所, 227 横浜市緑区長津田町 4259 \\ *川崎鉱業 (株), 260 千葉市新浜町 1 \\ **東京大学工学部工業化学科, 113 東京都文京区本郷 7-3-1 \\ *** 関東学院大学工学部機械工学科, 236 横浜市金沢区六浦町 4834 \\ ***** 横浜国立大学環境科学研究センター, 240 横浜市保土ヶ谷区常盤台 156 \\ ****** 東京理科大学理工学部工業化学科, 278 野田市山崎 2641
}

\section{Low Temperature Synthesis of Highly Conductive Transparent Films of F-doped Zinc Oxide}

Hideomi KOINUMA, Shunroh NAGATA*, Motoshi SASAKI**, Masashi KAWASAKI

Osamu TAKAI***, Jun-ichiroh MIZUSAKI**** and Kazuo FUEKI*****

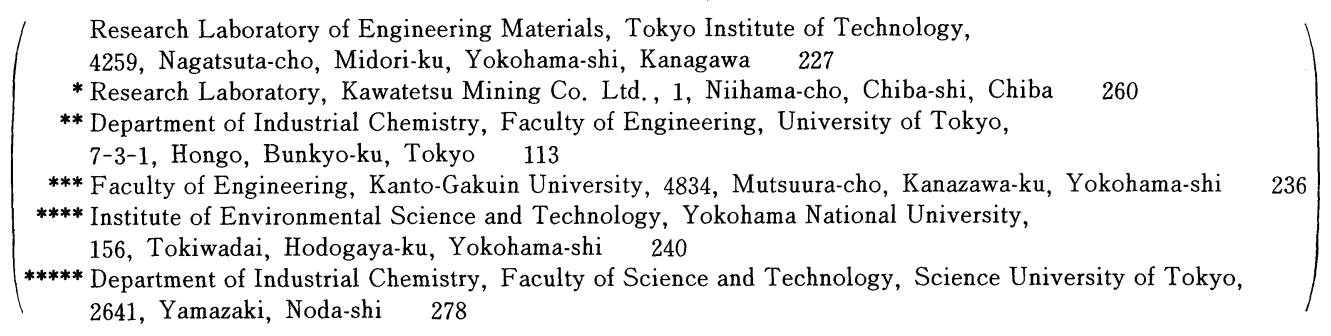

Highly conductive transparent films of $\mathrm{F}$-doped $\mathrm{ZnO}$ were prepared by an ion plating method in which metals were evaporated in vacuo in the presence of inductively coupled $r . f$. oxygen plasma. The reaction gases were pure oxygen and mixtures of oxygen and fluorine containing gases such as nitrogen trifluoride and silicon tetrafluoride. Crystalline films (2000 $\AA$ ) were prepared at a substrate temperature of $100^{\circ} \mathrm{C}$, and they had transmittances of about $90 \%$ and conductivities around $1000 \mathrm{~S} / \mathrm{cm}$.

[Received May 26, 1989 ; Accepted August 22, 1989]

Key-words : Fluorine doping, Zinc oxide, Transparent conductive oxide, Ion plating method, Thin film

\section{1. 緒言}

透明導電膜は，透明であるという光学的機能と導電性 という電子機能の両者を兼ね備えていることに特徴があ り，光の透過率と導電率に応じてさまざまな応用分野が ある.たとえば, アモルファスシリコン太陽電池用電極 には，膜形成のプロセス条件に耐える必要性からも， $\mathrm{SnO}_{2}$ などの酸化物が材料として最も広く使われてい る. しかし，エネルギー変換効率向上のためより低抵抗 化が求められるとともに, 高分子フィルム等の安価な材 料を基板として使用するために成膜温度の低温化等の改 良が求められている.

酸化物導電材料の導電メカニズムについては, 導電率 の酸素分圧依存性等の間接的なデータから, そのメカニ ズムが推定されてきだ1). 著者らは, 最近, 試料及び測 定条件を工夫することにより, $\mathrm{SnO}_{2}$ における酸素欠損 量の定量が可能であることを示し, その雾囲気依存性か
ら酸素欠損による導電メカニズムを明らかにしてい $る^{2)}$.

透明導電膜の作製方法としては，これまでに CVD， PVD ともにさまざまな方法が用いられている31 5). 著 者らは, 今回, 低温成膜に適しており, 付着力の強い膜 を作製することが可能といわれているイオンプレーティ ング法を用いて， $\mathrm{ZnO}$ 膜の作製をおこなった。同様の 方法では, Lau らにより, $\mathrm{Al}$ ドープ $\mathrm{ZnO}$ 膜についての 報告がある ${ }^{6)}$. 著者らは, $\mathrm{SnO}_{2}$ 系透明導電膜等で有効 性が報告されている77,8)，Fドープによる導電率の向上 も試みた. $\mathrm{NF}_{3}$ はシリコンの光酸化を促進することが 知られており ${ }^{9)}$ ，プラズマ中で分解生成した F 原子が ドーパントになるばかりでなく, 蒸発するZn の酸化を 促進する効果も期待した. フッ素源しして固体のフッ素 化合物を混入したターゲットを用いるスパッタリングな どに比べ，ガスとして導入することはプロセスの操作性 


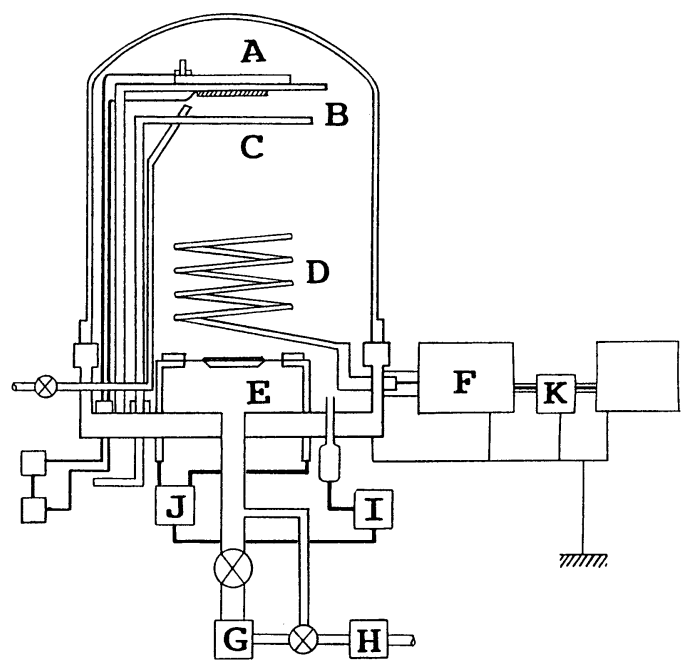

Fig. 1. Schematic representation of r.f. ion plating apparatus.

A : heater, B : substrate, C : shutter, D : r.f. coil, E : evaporation boat, $F$ : matching, box, $G$ : diffusion pump, $\mathrm{H}$ : rotary pump, I : vacuum gauge, J : P. I. D. unit, $\mathrm{K}:$ r.f. oscillator

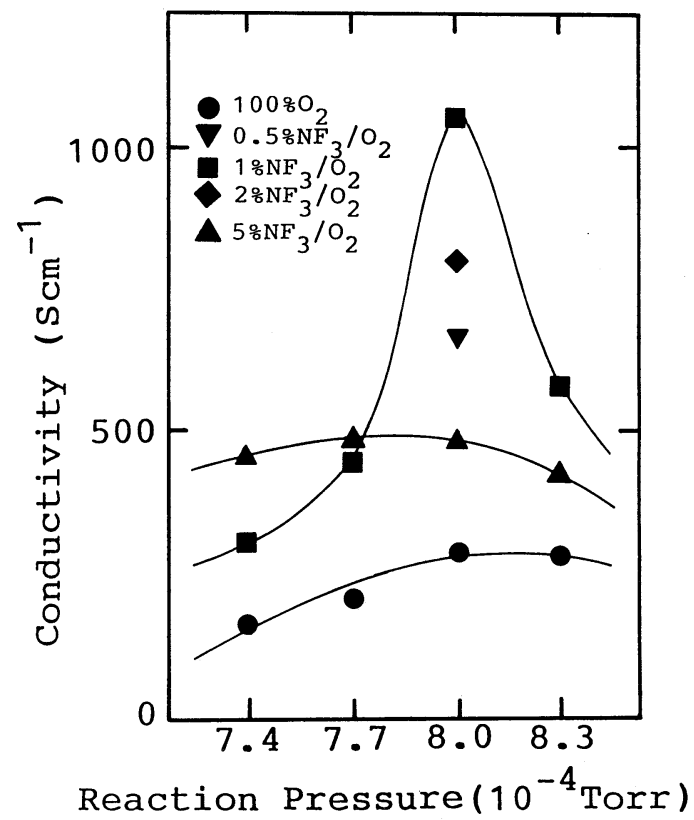

Fig. 2. Reaction pressure vs. conductivity for $\mathrm{ZnO}$ films : (thickness, $2000 \AA$ ).

にもすぐれている.

\section{1 実験装置}

\section{2. 実験方法}

使用したイオンプレーティング装置は, 真空蒸着装置 として市販されているチャンバー (ULVAC-VPC 250) をプラズマが併用できるように改造したものである，装
置の概略図を図 1 に示す.

高周波電源は $13.56 \mathrm{MHz}$ で, 電極は L カップルである. 基板は，チャンバー内上部にアルミニウム板で固定し， セラミックスヒーターで $100^{\circ} \mathrm{C}$ に加熱した。原料は, $\mathrm{Zn}$ 金属（フルウチ化学， $99.9 \%$ ) を使用し，蒸発用の るつぼは，Zn が昇華性の金属であるために $\mathrm{Ta}$ または Mo 製の昇華性金属用ボート（日本バックスメタル, B-4）を使用した.

使用したガスは，酸素ならびに酸素と $\mathrm{NF}_{3}$ または $\mathrm{SiF}_{4}$ の混合ガスで, 流量は $10 \mathrm{sccm}$, ガスの吹き出し 口は, 基板近傍となっている.

\section{2 反応制御}

本実験では $\mathrm{Zn}$ 蒸発速度を反応圧によって制御する方 法を利用した。すなわち, $\mathrm{Zn}$ 金属原子の蒸発量が増加 するほど，酸化により系内の酸素原子の減少する速度が 大きくなり，反応時の圧力が低くなる，定常的に金属が 蒸発している状態では, 反応圧が一定に保たれる.なお, このとき金属原子の蒸気圧は酸素の圧力に比べて十分に 小さいので無視してもよい. 実際の反応圧の制御は, PID 制御の温度コントローラ (大倉理研, EC 5000 B) を使用し，ペニング真空計からの反応圧入力を制御入力 信号とし原料蒸発用ボートの印加電力を制御するという 方法で, Zn の昇華速度を一定に保った. 成膜の開始と 終了は, 基板近傍のシャッターの開閉で行った.

\section{3 物性測定}

作製した膜の導電率は直流四端子法で，ホール効果は van der Pauw 法で $10 \mathrm{kG}$ の磁場を印加して測定した。 透過率は分光光度計（日立製作所, 340 形）を使い, $550 \mathrm{~nm}$ の波長の光の透過率を無蒸着の基板との比較法

Table 1. Transmittance $(550 \mathrm{~nm})$ of $\mathrm{ZnO}$ films prepared by $\mathrm{NF}_{3} / \mathrm{O}_{2}$ mixed gas series: (thickness, 2000 $\AA$ A).

\begin{tabular}{|c|c|c|}
\hline \multicolumn{2}{|c|}{ Reaction Conditions } & \multirow{2}{*}{$\begin{array}{c}\text { Transmittance } \\
(8)\end{array}$} \\
\hline $\begin{array}{l}\text { Gas Mixing Ratio } \\
\left.\mathrm{NF}_{3} / \mathrm{O}_{2} \text { ( } 8\right)\end{array}$ & $\begin{array}{c}\text { Pressure } \\
\left(10^{-4} \text { Torr }\right)\end{array}$ & \\
\hline \multirow[t]{3}{*}{0} & 7.7 & 88 \\
\hline & 8.0 & 87 \\
\hline & 8.3 & 92 \\
\hline 0.5 & 8.0 & 98 \\
\hline \multirow[t]{4}{*}{1.0} & 7.4 & 98 \\
\hline & 7.7 & 91 \\
\hline & 8.0 & 87 \\
\hline & 8.3 & 93 \\
\hline 2.0 & 8.0 & 91 \\
\hline \multirow[t]{4}{*}{5.0} & 7.4 & 92 \\
\hline & 7.7 & 92 \\
\hline & 8.0 & 90 \\
\hline & 8.3 & 92 \\
\hline
\end{tabular}




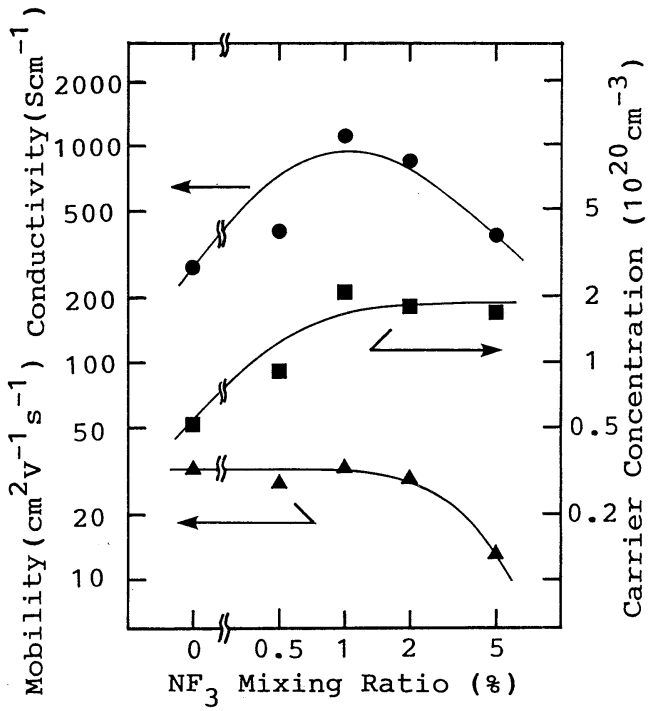

Fig. 3. Reaction gas mixing ratio $\left(\mathrm{NF}_{3} / \mathrm{O}_{2}\right)$ dependences of conductivity, carrier density and Hall mobility for $\mathrm{ZnO}$ films : (thickness, $2000 \AA$ ).

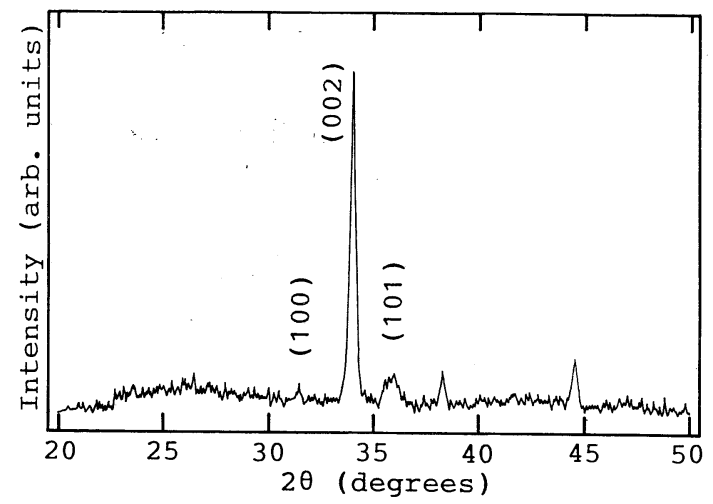

Fig. 4. X-ray diffraction pattern of $\mathrm{ZnO}$ film : (thickness, $2000 \AA$ ).

で求めた. 膜厚は触針法 (Taylor Hobson TALYSTEP) で測定した. 更に, X 線回折法 (理学電機, RAD- II C, $\mathrm{Cu} K \boldsymbol{\alpha}$ ) により膜の結晶性を測定し, XPS（日本電子, JPS-80）により膜中のFの分析をおこなった.

\section{3. 結果及び考察}

実験条件は, ガス流量 $10 \mathrm{sccm}$, 反応初期圧 $1 \times 10^{-3}$ Torr, 基板温度 $100^{\circ} \mathrm{C}$, 高周波出力 $100 \mathrm{~W}$ でおこなった. 反応圧は $(7.4 \sim 8.3) \times 10^{-4}$ Torr の範囲でおこない，堆 積時間は 20 分，堆積速度は $1.5 \sim 2.0 \AA / \mathrm{s}$ であった．基 板としては，コーニング \#7059 ガラスを使用した.

\section{$3.1 \mathrm{NF}_{3}$ 系ガスによる $\mathrm{ZnO}$ 膜の作製}

\subsection{1 透過率と導電率}

表 1 に示すように，作製した膜の透過率は反応圧が (7.4〜8.3) $\times 10^{-4}$ Torr の範囲内では，ガス組成に関係
なくいずれも $87 \%$ 以上の高い値となり，膜の酸化が十 分に進んでいることを示している.

作製した膜の導電率の測定結果を図 2 に示す. 反応圧 にかかわらず $\mathrm{NF}_{3}$ 混合ガスを用いて作製した膜の方が 酸素ガスのみで作製した膜よりも導電率が増加してい る. 特に, $\mathrm{NF}_{3} 1 \%$ の混合ガスを用いた場合に反応圧 $8.0 \times 10^{-4}$ Torr におて $1050 \mathrm{~S} / \mathrm{cm}$ (膜厚 $2000 \AA$ ) とい う高い導電率を示す膜が得られた。

\subsection{2 ホール効果}

作製した膜の電気的特性を調べるために，ホール効果 を測定した. 図 3 に反応圧 $8.0 \times 10^{-4}$ Torr のときの導 電率, キャリア濃度, ホール移動度のガス組成依存性を 示す.

図 3 から, 膜のキャリア密度は, 反応ガス中への $\mathrm{NF}_{3}$ 混合割合が $1 \%$ までは増加するが, それ以上では 変化がなく, 逆にホール移動度は, $\mathrm{NF}_{3}$ 混合割合が $2 \%$ までは変化しないが，それ以上では，低下している，F の添加が，低濃度ではキャリアの増加につながるが，過 剰になると移動度の低下を招くと思われる. 以上の結果 として, キャリア濃度とホール移動度の積として与えら れる膜の導電率は, $\mathrm{NF}_{3} 1 \%$ のときに最大值をもつこと がわかる。

また，ガス組成を $\mathrm{NF}_{3} 1 \%$ の条件で固定し反応圧を 変化させた場合, 膜のホール移動度は変化しないが, キャ リア濃度が $8.0 \times 10^{-4}$ Torr のときに最大となっており， このため膜の導電率も $8.0 \times 10^{-4}$ Torr のときに最大と なることがわかった。

\subsubsection{X 線回折測定結果}

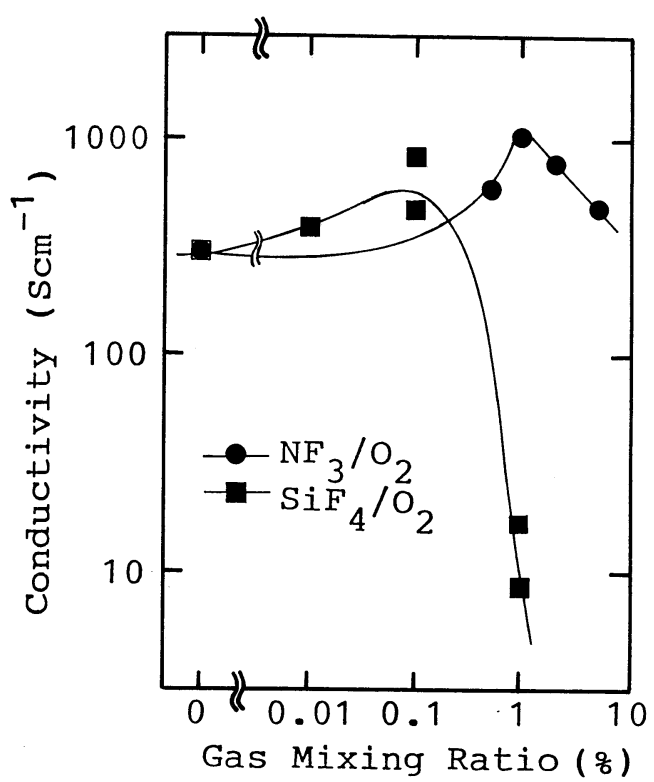

Fig. 5. Reaction gas mixing ratio vs. conductivity for ZnO films : (thickness, $2000 \AA$ ). 


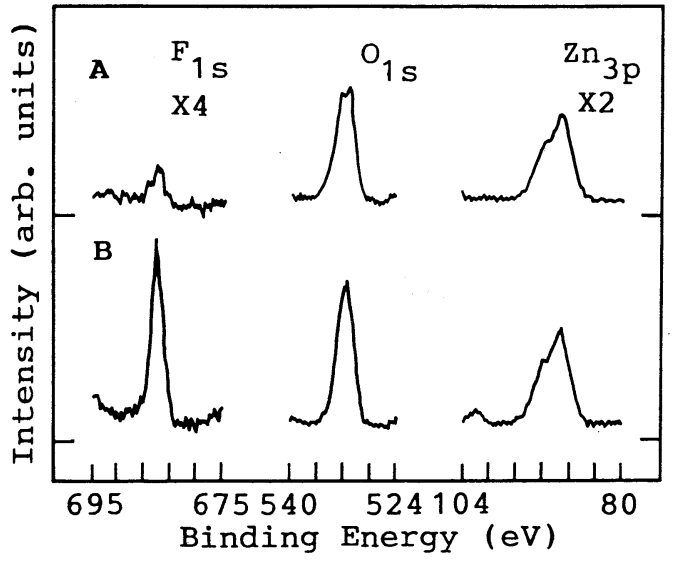

Fig. 6. XPS spectrum of $\mathrm{ZnO}$ film surface. A : $1 \% \mathrm{NF}_{3}$ in oxygen, $8 \times 10^{-4}$ Torr $\mathrm{B}: 1 \% \mathrm{SiF}_{4}$ in oxygen, $8 \times 10^{-4}$ Torr

図 4 に作製した膜（表 1，No.4）のX線回折デー夕 を示す. 成膜温度が $100^{\circ} \mathrm{C}$ という低い温度にもかかわ らず膜は結晶化しており，更に比較的 $c$ 軸方向に配向 した膜となっている. 作製した膜がいずれも比較的高い 導電率を示していたのは, このように膜が結晶化してい たことにも一因があると考えられる.

\section{3. $2 \mathrm{SiF}_{4}$ 系ガスによる $\mathrm{ZnO}$ 膜の作製}

反応圧 $8.0 \times 10^{-4}$ Torr において作製した膜の，導電 率のガス組成依存性を図 5 に示す. $\mathrm{SiF}_{4}$ 混合の場合で も $\mathrm{NF}_{3}$ と同様に, 少量 ( $0.1 \%$ 以下) の混合において は作製した膜の導電率に増加がみられるが，混合割合が 過剰になると $\mathrm{NF}_{3}$ の場合以上に極端な低下がみられる. また，ガスの最適混合割合は， $\mathrm{NF}_{3}$ の場合に比べて 1 けた低下している.

なお, 成膜速度や膜の透過率は, $\mathrm{NF}_{3}$ の場合とほと んど違いがみられなかった。

\section{$3.3 \mathrm{XPS}$ による膜組成の分析}

XPS により，作製した膜の組成分析をおこなった。 図 6 に, $\mathrm{NF}_{3}$ 及び $\mathrm{SiF}_{4}$ それぞれの混合ガスを使用して 作製した膜表面の, XPS 測定データを示す.いずれも, ガスの混合割合は酸素ガス中 $1 \%$ と同じではあるが，膜 中へのFの混入量は大きく異なり, 膜表面では $\mathrm{NF}_{3}$ の 場合に $1.3 \%$ であったものが, $\mathrm{SiF}_{4}$ で $12 \%, \mathrm{Ar}$ スパッ 夕 $(1 \mathrm{kV}, 60$ 秒, エッチング深さ約 $1000 \AA)$ 後の膜内 部の分析ではそれぞれ $0.4 \%$ と $8.5 \%$ であった. $\mathrm{SiF}_{4}$
混合ガスを使用して作製した膜の方が，膜へのFの取り 込みが促進されることがわかる. この測定結果は, 前に 述べた膜の導電率と反応ガスの組成との関係（図 5) に おいて, その最適混合割合が $\mathrm{SiF}_{4}$ 混合ガスを使用した 場合に 1 けた低くできるという結果とも一致する.この ことは, $\mathrm{SiF}_{4}$ が $\mathrm{NF}_{3}$ よりもプラズマにより分解されや すく, その結果として作製した膜中へのFの取り込み量 も増加するためと思われる.

\section{4. 結 言}

著者らは, 今回イオンプレーティング法により $\mathrm{ZnO}$ 膜を作製する際に，F系のガス $\left(\mathrm{NF}_{3}, \mathrm{SiF}_{4}\right)$ と酸素の 混合ガスをプラズマ発生に使用した. 基板温度 $100^{\circ} \mathrm{C}$ で作製した膜において結晶性が良く, 可視光透過率が $87 \%$ で導電率が $1050 \mathrm{~S} / \mathrm{cm}$ と導電性の高い膜を得るこ とができ, 更に, 以下のような知見を得た.

（1）膜中へのFのドープが，膜のキャリア濃度を増 加させ，それが膜の導電率の増加につながる.

（2） Fの過剩ドープは,ホール移動度の低下を招き, それに伴い膜の導電率も低下する.

( 3 ) $\mathrm{O}_{2}$ 中への混合ガスとして $\mathrm{NF}_{3}$ と $\mathrm{SiF}_{4}$ の 2 種 類のガスを比較すると, $\mathrm{SiF}_{4}$ の方がプラズマによって 分解し易く，膜中へも取り込まれ易い.

謝辞 イオンプイレーティング装置の作製にあたっては, 有用なアドバイスをいただいた, 東洋大学の柏木助教授に感謝 します。

\section{文献}

1) S. Samson and C. G. Fonstand, J.Appl. Phys., 44, 4618 (1973).

2) H. Koinuma, J. Shimoyama, J. Mizusaki, M. Kawasaki and K. Fueki, Ext. Abst. of 18th International Conf. on Solid State Devices and Materials, Tokyo, 763-64 (1986).

3）御子柴均, 表面, 18, 440 (1980).

4）水橋 衛, 安達邦彦, セラミックス, 19, 295 (1984).

5）鈴木巧一, 水橋 衛, 機能材料, 9, 5 (1984).

6) W.S. Lau and S. J. Fonash, J. Electron. Mater., 16,141 (1987).

7) A. Bardway, B. K. Gupta, A. Raza, A. K. Sharma and O. P. Agnihorti, Solar Cells, 5, 39 (1981-1982).

8) H. Koinuma, M. Kawasaki, K. Masubuchi and K. Fueki, Yogyo-Kyokai-Shi, 95, 569-79 (1987).

9) M. Morita, T. Kubo, T. Ishihara and M. Hirose, Ext. Abst. of 16th International Conf. on Solid State Devices and Materials, Kobe, 455-58 (1984). 